\title{
Conservation of Indigenous Vegetables from a Hotspot in Tropical Asia: What Did We Learn from Vavilov?
}

\author{
Svein Ø. Solberg * and Yu-Yu Chou \\ Theme Germplasm, World Vegetable Center, Tainan, Taiwan
}

Keywords: biodiversity, crop wild relative, geography, genetic resources, genebank, horticulture, vegetable

\section{CROP DIVERSITY AND GEOGRAPHY}

Conservation biologists have allocated an Indo-Burma biodiversity hotspot among 34 regions around the world especially rich in plants, animals, and other species (Myers et al., 2000). More than 13,500 different vascular plant species, of which 7000 are endemic, have been detected in this hotspot (Tordoff et al., 2012). Ninety years ago, the Russian scientist Vavilov (1926) pointed to the richness of cultivated plant species and their crop wild relatives in certain areas around the

\section{OPEN ACCESS}

Edited by:

Paul Christiaan Struik

Wageningen University and Research Centre, Netherlands

Reviewed by: Samuel Rezende Paiva, EMBRAPA Labex US-Secretariat of International Affairs, Brazil

Robert Henry,

University of Queensland, Australia

*Correspondence: Svein Ø. Solberg svein.solberg@worldveg.org

Specialty section: This article was submitted to Crop Science and Horticulture, a section of the journal Frontiers in Plant Science

Received: 04 August 2016 Accepted: 13 December 2016 Published: 04 January 2017

Citation:

Solberg SØ and Chou Y-Y (2017)

Conservation of Indigenous Vegetables from a Hotspot in Tropical Asia: What Did We Learn from Vavilov? Front. Plant Sci. 7:1982. doi: 10.3389/fp/s.2016.01982 world, of which the Tropical Asia Center was one of eight. Later, Zeven and Zhukovsky (1975) applied the term Indochinese-Indonesian region of diversity for the area, which by then had been divided by various authors into an Indochinese region including Myanmar, Laos, Cambodia, Thailand, Bangladesh, and parts of Northeastern India and Southern China, and a more southern region including Malaysia and Indonesia (Darlington, 1956; Li, 1969; Schery, 1972; Janick, 2002; Nandwani, 2014). Rice (Oryza sp.), mungbean (Vigna radiata), gourd species, and indigenous vegetables were among crops that Zeven and Zhukovsky (1975) listed in the Indochinese region of diversity.

Vavilov noted the importance of collecting different varieties, and the wild relatives, of cultivated plants as genetic resources for use in crop improvement. In 1935, he claimed that for plant breeders there was no other choice but to become geographers (Vavilov, 1935). At that time, the genepool available to plant breeders was relatively narrow. To adapt crops to a wider geographical zone and to move forward in breeding, Vavilov started collecting germplasm worldwide and conducted expeditions to India, China, and other locations. He also received samples of leguminous species from Myanmar. In a later overseas collection mission in Myanmar, Kobylyanskaya, and Chepurin from the Vavilov Institute collected 201 accessions of cereals and legumes from the central and south parts of the country (Loskutov, 1999). More recently, Japanese scientists have conducted missions to Myanmar to collect wild rice (Uga et al., 2004).

As global populations increase and climates change, a greater diversity of genetic resources is needed for crop improvement. Agriculture needs to produce more food under more unpredictable climatic conditions (McCouch et al., 2013; Nierenberg, 2013; Betts and Hawkins, 2014). Genetic resources have indeed been collected; according to the UN Food and Agriculture Organization (FAO, 2010), rice is well-represented, with more than 770,000 accessions in genebanks around the world. Horticultural crops such as vegetables tend to be highly underrepresented in the conservation system, especially considering their nutritional importance (Yang and Hanson, 2009). Here we demonstrate, despite 90 years of awareness, how indigenous vegetables are poorly represented in the global conservation system and argue for the importance of safeguarding agrobiodiversity in its centers of diversity. We use tropical Asia as a case area but narrow our focus to Myanmar and indigenous vegetables relevant for this country. 


\section{MYANMAR AND TARGET CROPS}

Myanmar is within a recognized region of diversity of several cultivated plants. The country has a tropical monsoon climate, a distinct wet and warm summer and a dry and relatively warm winter. The current population is 51.7 million. Myanmar is a member of the Association of Southeast Asian Nations (ASEAN) and recently joined the ASEAN economic community. Agriculture is important and generates more than $20 \%$ of export earnings and employs more than $60 \%$ of the labor force (MOAI, 2015). Rice is cultivated on two thirds of the arable land; around 1 million tons of rice are exported annually. Pulses are the second most important crop, grown on 4.5 million ha, and include species such as black gram and mungbean (green gram). Vegetables are grown on around 0.8 million ha, principally in the highlands but also in household gardens or smallscale market gardens throughout the country. The conservation system of plant genetic resources in Myanmar is organized by the Department of Agricultural Research with national seed and field collections and a common information system maintained at the Myanmar Seed Bank and funded by the government of Japan (FAO, 2016).

We were interested in vegetable crops that Zeven and Zhukovsky (1975) linked to Tropical Asia and Myanmar as region of diversity. They used the term "S. Asia" for this area in contrast to SE. Asia, which was used for the more southern area including Malaysia and Indonesia. Typical medicinal plants, bamboo species, and starch plants were not included, although some would call them vegetables. In addition, a second list of vegetable crops was made based on those regarded as important indigenous vegetables in Myanmar today by national agricultural experts from the Seed Bank Myanmar, Department of Agricultural Research, or as presented in a publication of important food plants in Myanmar (Watanbe et al., 1999). The two lists were merged and more than 30 target species were identified (Table 1).

The Integrated Taxonomic Information System was applied (ITIS, 2016) to verify the species taxonomic and common names. Each species was then examined by surveying two global databases: the Global Biodiversity Information Facility (GBIF, 2016) and the Global Gateway to Genetic Resources (GENESYS, 2016). GBIF was applied to survey the number of occurrences, applying the scientific names and country filters in the search function. GBIF (2016) occurrences are the recorded number of observations of a species as natural populations, herbarium specimens, seed collects, or others. GENESYS (2016) records reflect the conservation status of plant genetic resources. GENESYS was applied to survey the number of conserved accessions, applying the scientific names and country of origin as filters in the search function. In GENESYS, combined searches were used; for example for mungbean, different taxa, and authors were combined including Vigna radiata var. radiate, Vigna radiata (L.) R. Wilczek var. radiate, Vigna radiate, Vigna radiata (L.) R. Wilczek var. radiate, Vigna radiata (L.) R. wilczek, and Vigna radiata (L.) R.Wilczek. Filters used are given as Supplementary Material (Table S1).

\section{SPECIES OCCURRENCES}

In GBIF (2016), a total of 108,787 occurrences from Myanmar were reported, which was $<0.02 \%$ out of the global number of $645,184,811$. Of targeted species, there were the most records from Myanmar on Senegalia pennata (climbing wattle), a wild tree not mentioned by Zeven and Zhukovsky (1975), its leaves are collected and used as a vegetable, followed by Cajanus cajan (pigeon pea), a grain legume not included in the Indochina region of diversity (Table 1). Of the species with Indochina as the region of diversity, Trichosanthes cucumerina (snake gourd), Momordica charantia (bitter gourd), and Vigna radiata (mungbean) each had four to seven records from Myanmar in GBIF, which were herbarium specimens or seed collects. These are very low numbers, but they do not necessarily reflect the importance or the presence of the species. Rather, this can be a result of few botanic studies or no reporting from the country to GBIF.

\section{CONSERVATION STATUS}

In GENESYS (2016), a total number of 4092 accessions with Myanmar as country of origin were reported, which was $0.16 \%$ out of the global number of $2,573,870$ accessions. Targeted vegetable species had from 0 to 20,000 conserved accessions globally, but only with 0-70 accessions from Myanmar depending on the species (Table 1). Mungbean was relatively well-represented in genebanks around the world, but had only a very few accessions from Myanmar; a country mentioned as the primary region of diversity by Zeven and Zhukovsky (1975). In contrast, India is represented by 5154 mungbean accessions in GENESYS. The overall underrepresentation of indigenous vegetables from Tropical Asia is clear. In total, 451 accessions of bitter gourd were reported in GENESYS, none with Myanmar as country of origin, and 81 accessions of the leafy vegetable kangkong (Ipomoea aquatica) were reported, also with none from Myanmar. As a comparison, rice (Oryza sp.) has 208,447 accessions in GENESYS (and 3543 accessions with Myanmar as country of origin). Among the reported bitter gourd accessions 50 were from Thailand, 40 from Bangladesh, 32 from Cambodia, and 0 from Myanmar-all countries regarded as part of the primary region of diversity. Among the kangkong accessions 27 were from Thailand, 4 from Cambodia and again, 0 from Myanmar. These numbers are all very low. Both bitter gourd and kangkong are common in smallholder gardens in Myanmar and other tropical Asian countries. The crops may likely be present as semi-wild, naturalized populations, as locally cultivated material (landraces), or as modern varieties. GENESYS does not capture all conserved germplasm, as there are collection holders that do not report to the global database. However, surveying the database gives a guideline of the conservation status. A crop such as bitter gourd is used all over tropical Asia, the plant is related to cucumber, and it has several positive health effects, including being good for lowering blood sugar levels (Leung et al., 2009). Kangkong is a nutritious leafy vegetable that can stand wet conditions and flooding (Irfanullah et al., 2011), and thus has potential for climate change adaptation. 
TABLE 1 | Targeted species, their region of diversity, number of occurrences, and number of conserved accessions globally and with Myanmar as country of origin.

\begin{tabular}{|c|c|c|c|c|c|}
\hline \multirow[t]{2}{*}{ Scientific and common name } & \multirow[t]{2}{*}{$\begin{array}{l}\text { Region of } \\
\text { diversity }\end{array}$} & \multicolumn{2}{|c|}{$\begin{array}{l}\text { No. of occurrences } \\
\text { GBIF (2016) }\end{array}$} & \multicolumn{2}{|c|}{$\begin{array}{l}\text { No. of accessions } \\
\text { GENESYS (2016) }\end{array}$} \\
\hline & & Global & Myanmar & Global & Myanmar \\
\hline \multicolumn{6}{|c|}{ VEGETABLE SPECIES WITH DIVERSITY CENTER INCLUDING MYANMAR } \\
\hline Vigna radiata (mungbean) & India, Myanmar & 11,879 & 4 & 11,953 & 10 \\
\hline Wolffia arrhiza (spotless watermeal) & India, Myanmar & 10,223 & 0 & 0 & 0 \\
\hline Momordica charantia (bitter gourd) & TAsia & 6044 & 5 & 451 & 0 \\
\hline Ocimum basilicum (sweet basil) & T Asia & 3083 & 0 & 444 & 0 \\
\hline Oenanthe javanica (Chinese celery) & Indochina & 3066 & 2 & 3 & 0 \\
\hline Mucuna pruriens (Cochichina) & T Asia & 2220 & 6 & 48 & 0 \\
\hline Vigna mungo (black gram) & India, Myanmar & 1929 & 2 & 1518 & 0 \\
\hline Luffa aegyptiaca (sponge gourd) & India, T Asia & 1583 & 4 & 532 & 1 \\
\hline Amaranthus tricolor (amaranth) & T Asia & 1248 & 0 & 473 & 0 \\
\hline Basella alba (Indian spinach) & T Asia & 1051 & 5 & 170 & 0 \\
\hline Trichosanthes cucumerina (snake gourd) & T Asia & 963 & 7 & 46 & 0 \\
\hline Neptunia oleracea (garden puff) & T Asia & 937 & 2 & 9 & 0 \\
\hline Psophocarpus tetragonolobus (winged bean) & T Asia & 839 & 1 & 485 & 0 \\
\hline Benincasa hispida (waxgourd) & T Asia & 513 & 1 & 383 & 0 \\
\hline Canavalia gladiata (sword jackbean) & Myanmar & 349 & 3 & 28 & 0 \\
\hline Sesbania grandiflora (veg. hummingbird) & T Asia & 6 & 0 & 114 & 0 \\
\hline \multicolumn{6}{|c|}{ INDIGENOUS VEGETABLES IMPORTANT FOR MYANMAR ${ }^{B}$ BUT FROM OTHER DIVERSITY CENTERS } \\
\hline Vigna unguiculata (cowpea) & Africa, India & 37,203 & 2 & 19,429 & 4 \\
\hline Brassica nigra (black mustard) & Europe & 19,824 & 0 & 231 & 0 \\
\hline Cajanus cajan (pigeon pea) & Africa, India & 17,439 & 14 & 13,590 & 74 \\
\hline Sinapis alba (white mustard) & Europe & 14,471 & 0 & 538 & 0 \\
\hline Phaseolus lunatus (Lima bean) & C America & 9268 & 1 & 6088 & 2 \\
\hline Solanum melongena (eggplant) & India, China & 5831 & 7 & 5487 & 6 \\
\hline Hibiscus cannabinus (roselle) & Africa & 5370 & 3 & 553 & 0 \\
\hline Lagenaria siceraria (bottle gourd) & Africa & 2551 & 1 & 1172 & 1 \\
\hline Colocasia esculenta (wild taro) & SE Asia & 2266 & 1 & 0 & 0 \\
\hline Ipomoea aquatica (kangkong) & No info & 1977 & 7 & 81 & 0 \\
\hline Pachyrhizus erosus (ice potato) & S America & 1310 & 0 & 83 & 0 \\
\hline Nelumbo nucifera (lotus) & C Asia & 1060 & 3 & 2 & 0 \\
\hline Sechium edule (chayote) & C America & 900 & 0 & 6 & 0 \\
\hline Artocarpus heterophyllus (jackfruit) & India & 868 & 0 & 15 & 0 \\
\hline Luffa acutangula (sponge gourd) & India & 759 & 3 & 551 & 0 \\
\hline Senegalia pennata (climbing wattle) & & 685 & 18 & 0 & 0 \\
\hline Amorphophallus paeoniifolius (elephant yam) & SE Asia & 570 & 1 & 3 & 0 \\
\hline Dolichos lablab (lablab bean) & Africa & 565 & 0 & 16 & 0 \\
\hline Centella erecta (Asian pennywort) & No info & 297 & 0 & 0 & 0 \\
\hline Combretum indicum (Rangoon creeper) & SE Asia & 260 & 0 & 1 & 0 \\
\hline Lablab vulgaris (summer bean) & No info & 53 & 0 & 0 & 0 \\
\hline
\end{tabular}

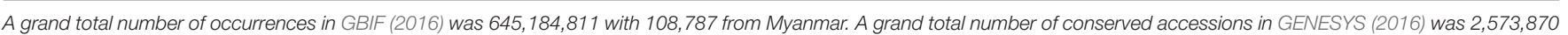
with 4092 accessions with Myanmar as country of origin.

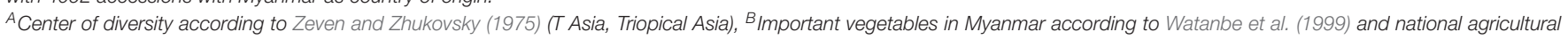
expertise.

\section{OUTLOOK}

Myanmar is experiencing significant economic and political changes (Asian Development Bank, 2012). Its agricultural sector is evolving; seed companies are establishing; and new cultivars are being introduced (Asian Development Bank Institute, 2013; MOAI, 2016). Ongoing changes imply that important plant genetic resources in a recognized region of diversity may be threatened. We have demonstrated that today such genetic resources are sparsely represented in global collections. As 
gaps have been identified, new collection missions should be conducted. This should be done to safeguard the genetic resources and also to facilitate access for breeding and research as outlined in the International Treaty on Plant Genetic Resources for Food and Agriculture (ITPGRFA, 2001). One problem is that most vegetables, and almost all indigenous vegetables, are not explicitly mentioned in Annex 1 of the Treaty. Furthermore, the Convention of Biological Diversity and the Nagoya Protocol on Access and Benefit Sharing (ABS, 2014) has made overseas collection missions complicated (Cressey, 2014; Maggioni et al., 2015). Ninety yeas after Vavilov published his work on Centers of Origin, there are still huge gaps in global collections. Although some major crops have been extensively collected, indigenous vegetables from tropical Asia, and especially from Myanmar, are poorly represented. Such vegetables have great potential to add vital nutrients to human diets (Yang and Hanson, 2009), diversify cropping systems (Subbarao et al., 2005), and increase smallholders' incomes and livelihoods (Ebert, 2014). Indeed, there are challenges ahead: What Vavilov once did is difficult to do today. Now, each country tends to guard its domain; some countries look more inwards than outwards,

\section{REFERENCES}

ABS (2014). Nagoya Protocol on Access and Benefit Sharing. Rome: Food and Agriculture Organization of the United Nations.

Asian Development Bank (2012). Myanmar in Transition: Opportunities and Challenges. Manila: Asian Development Bank.

Asian Development Bank Institute (2013). Developing a Competitive Seed Industry in Myanmar. CLMV Project Policy Brief. Tokyo: Asian Development Bank Institute.

Betts, R. A., and Hawkins, E. (2014). "Climate projections,". in Plant Genetic Resources and Climate Change, eds M. Jackson, B. Ford-Lloyd, and M. Parry (Boston, MA: CABI), 38-60.

Cressey, D. (2014). Biopiracy ban stirs red-tape fears. Nature 514, 14-15. doi: $10.1038 / 514014 a$

Darlington, C. D. (1956). Chromosome Botany and the Origins of Cultivated Plants. Revised 2nd Edn. Crows Nest, NSW: G. Allen \& Unwin Ltd.

Ebert, A. W. (2014). Potential of underutilized traditional vegetables and legume crops to contribute to food and nutritional security, income and more sustainable production systems. Sustainability 6, 319-335. doi: $10.3390 /$ su6010319

FAO (2010). The Second Report on the State of the World's Plant Genetic Resources for Food and Agriculture. Rome: FAO.

FAO (2016). National Information Sharing Mechanism. Available online at: http://www.fao.org/pgrfa-gpa-archive/mmr/mmrwelcomeil.html (Accessed on November 9, 2016)

GBIF (2016). The Global Biodiversity Information Facility. Available online at: http://www.gbif.org (Accessed on June 20, 2016).

GENESYS (2016). The Global Gateway to Genetic Resources. Available online at: https://www.genesys-pgr.org (Accessed on June 20, 2016).

Irfanullah, H. M., Azad, M. A. K., Kamruzzaman, M. D., and Wahed, M. A. (2011). Floating gardening in Bangladesh: a means to rebuild lives after devastating flood. Indian J. Tradit. Know. 10, 31-38.

ITIS (2016). Integrated Taxonomic Information System. Available online at: http://www.itis.gov/ (last Retrieved June 20 2016).

ITPGRFA (2001). The International Treaty on Plant Genetic Resources for Food and Agriculture. Rome: Food and Agriculture Organization of the United Nations.

Janick, J. (2002). History of Horticulture. West Lafayette, IN: Purdue University.

Leung, L., Birtwhistle, R., Kotecha, J., Hannah, S., and Cuthbertson, S. (2009). Antidiabetic and hypoglycaemic effects of Momordica charantia (bitter melon): a mini review. Brit. J. Nutr. 102, 1703-1708. doi: 10.1017/S0007114509992054 complicating the access of enterprises and research institutions to genetic material. To paraphrase Vavilov: Plant breeders are restricted from being geographers. Such constraints hinder the best efforts of agriculture to face the grand challenges of our time. International organizations, national policy makers, research institutions, and enterprises should work together and find joint solutions to safeguard and utilize the great potential of plant genetic resources.

\section{AUTHOR CONTRIBUTIONS}

SS had the idea and contributed by co-ordination the writing. YC contributed by database searches and comments.

\section{SUPPLEMENTARY MATERIAL}

The Supplementary Material for this article can be found online at: http://journal.frontiersin.org/article/10.3389/fpls.2016. 01982/full\#supplementary-material

Table S1 | Scientific names applied as filters in the search function in GENESYS.
Li, H. L. (1969). The vegetables of ancient China. Econ. Bot. 23, 253-260. doi: $10.1007 / \mathrm{BF} 02860457$

Loskutov, I. G. (1999). Vavilov and His Institute. A History of the World Collection of Plant Genetic Resources in Russia. Rome: International Plant Genetic Resources Institute.

Maggioni, L., Noriega, I. L., Lape-a, I., Holubec, V., and Engels, J. M. M. (2015). Collecting Plant Genetic Resources in Europe: A Survey of Legal Requirements and Practical Experiences. Leiden: International Law E-Books.

McCouch, S., Baute, G. J., Bradeen, J., Bramel, P., Bretting, P. K., Buckler, E., et al. (2013). Agriculture: feeding the future. Nature 499, 23-24. doi: $10.1038 / 499023$ a

MOAI (2015). Myanmar Agriculture in Brief 2015. Nay Pyi Taw: The government of the Republic of the Union of Myanmar. Ministry of Agriculture and Irrigation, Department of Planning.

MOAI (2016). Myanmar: National Action Plan for Agriculture (NAPA) Working Paper 1: Crop Production, Extension and Applied Research. Nay Pyi Taw: The government of the Republic of the Union of Myanmar. Ministry of Agriculture, Livestock and Irrigation.

Myers, N., Mittermeier, R. A., Mittermeier, C., da Fonseca, G. A. B., and Kent, J. (2000). Biodiversity hotspots for conservation priorities. Nature 403, 853-858. doi: $10.1038 / 35002501$

Nandwani, D. (2014). Sustainable Horticultural Systems: Issues, Technology and Innovation (Sustainable Development and Biodiversity). Cham: Springer International Publishing.

Nierenberg, D. (2013). “Agriculture: Growing food - and solutions," in State of the World. Is Sustainability Still Possible?, eds E. Assadourian and T. Prugh (Washington, DC; Covelo, CA; London, CT: Island Press), 190-200.

Schery, R. W. (1972). Plants for Man. Englewood Cliffs, NJ: Prentice Hall.

Subbarao, G. V., Ito, O., Serraj, R., Crouch, J. H., Tobita, S., Okada, K., et al. (2005). "Physiological perspectives on improving adaptation to drought Justification for a systemic component-based approach," in Handbook of Photosynthesis, 2nd Edn, ed M. Pessaraki (Boca Raton, FA: CRC Press), 577-594.

Tordoff, A. W., Bezuijen, M. R., Duckworth, J. W., Fellowes, J. R., Koenig, K., Royo, A. G., et al. (2012). Ecosystem Profile Indo-Burma Biodiversity Hotspot 2011 Update. Arlington, VA: Critical Ecosystem Partnership Fund.

Uga, Y., Oo, T. M., Twa, W., and Kawase, M. (2004). Exploration and Collection of Wild Rice in Northern and Western Region of Myanmar. Available online at http://www.gene.affrc.go.jp/index_en.php (Accessed on November 9, 2016). 
Vavilov, N. I. (1926). Studies on the origin of cultivated plants. (Russian) Bull. Appl. Bot. Plant Breeding 14, 1-245.

Vavilov, N. I. (1935). "Theoretical Basis for Plant Breeding," in Origin and Geography of Cultivated Plants, Vol. 1, The Phytogeographical Basis for Plant Breeding Moscow, Transl. by D. Love (Cambridge: Cambridge University Press), 316-366.

Watanbe, S., Tananka, H., Ito, M., and Irie, K. (1999). Useful Plants in Myanmar. Nay Pyi Taw: Central Agricultural Research Institute.

Yang, R. Y., and Hanson, P. (2009). Improved food availability for food security in Asia-Pacific region. Asia Pac. J. Clin. Nutr. 18, 633-337

Zeven, A. C., and Zhukovsky, P. M. (1975). Dictionary of Cultivated Plants and Their Centres of Diversity - Excluding Ornamentals, Forest Trees and Lower Plants. Wageningen: Centre for Agricultural Publishing and Documentation.

Conflict of Interest Statement: The authors declare that the research was conducted in the absence of any commercial or financial relationships that could be construed as a potential conflict of interest.

Copyright (๑) 2017 Solberg and Chou. This is an open-access article distributed under the terms of the Creative Commons Attribution License (CC BY). The use, distribution or reproduction in other forums is permitted, provided the original author(s) or licensor are credited and that the original publication in this journal is cited, in accordance with accepted academic practice. No use, distribution or reproduction is permitted which does not comply with these terms. 